\title{
Effects of estrogen deprivation due to breast cancer treatment
}

\author{
$N$ Angelopoulos, V Barbounis ${ }^{1}, S$ Livadas, D Kaltsas and G Tolis
}

Endocrine Department, 'Hippokrateion' Hospital of Athens, Athens, Greece

${ }^{1}$ 2nd Department of Medical Oncology, St Savas Oncology Hospital, 171 Alexandra's Avenue, Athens 115-22, Greece

(Requests for offprints should be addressed to N Angelopoulos, Division of Endocrinology and Metabolism, 'Hippokrateion' Hospital of Athens, Vassilisis Sofias Avenue 108, 11527 Athens, Greece; Email: drangelnick@ hotmail.com)

\begin{abstract}
Breast cancer is one of the main life-threatening diseases that a woman may have to face during her lifetime. The increasing incidence of breast neoplasia reported over the last few decades has led to widespread screening of women resulting in early diagnosis. One common but challenging question for most doctors, after the surgical excision of the lesion, is determination of the ideal adjuvant therapy for their patients for the achievement of maximum life expectancy with the best quality of life.

Since the beginning of the last century, the knowledge that breast cancer arises from hormoneresponsive tissues has long made use of hormone-blocking agents in the beneficial treatment of breast neoplasia. The discovery of new molecules with endocrine actions has rendered the use of adjuvant therapy in a tailor-made pattern too complicated, as these agents have a different mode of action, different adverse effects and probably different indications.

The aim of the present review is to clarify these issues, analyzing the mechanism of action of available drugs and their actions on specific areas of uncertainty: cognitive function, cardiovascular system, urogenital tract, bone metabolism, weight gain, hot flushes and premature menopause. Regarding the efficacy of adjuvant therapy, there has been particular focus on the multiple hormonal-induced consequences of each regimen in order to provide the clinician with the available data for choosing the ideal therapy for the patient.
\end{abstract}

Endocrine-Related Cancer (2004) 11 523-535

\section{Introduction}

Adjuvant therapy in breast cancer consists of hormonal therapy with or without chemotherapy given after surgical excision of the tumor. The goal of hormonal adjuvant treatment in early breast cancer is the inhibition of estrogen trophic function in malignant cells (Doisneau-Sixou et al. 2003). Initially, hormonal therapy was based on surgical ablation (ovariectomy, adrenalectomy, hypophysectomy) and the use of androgens, progestagens or combined estrogen-progestagens limited to postmenopausal women (Paterson \& Russel 1959). High-dose estrogen was generally considered the endocrine therapy of choice for postmenopausal women with breast cancer, and diethylstilbestrol (DES), the first orally active artificial estrogen, was commonly administered for the therapy of advanced breast cancer before the introduction of contemporary endocrine therapy. A major advance was made with the introduction of tamoxifen (a selective estrogen receptor modulator (SERM) which was the first commercially available anti-estrogen agent), considered as the standard treatment for patients with breast cancer positive in estrogen receptors (ERs), because it causes fewer side-effects than DES (Smith \& Good 2003). Megestrol acetate, in North America, and aminoglutethimide, in Europe, had previously been the traditional second-line therapies after tamoxifen in advanced breast cancer. Other hormonal approaches, such as the use of aromatase inhibitors, fulvestrant (a selective downregulator of ERs), gonadotropin-releasing hormone $(\mathrm{GnRH})$ analogues, raloxifene (SERM), oophorectomy, and chemical and radiological ovarian ablation, have been applied as alternative methods in ER-positive patients. 


\section{Background}

\section{Efficacy of adjuvant hormonal treatment}

Adjuvant endocrine therapy is recommended for nearly all women with a breast tumor that expresses ERs or progesterone receptors. The first critical overview of data unequivocally demonstrated that tamoxifen was associated with a highly significant improvement in relapsefree and overall survival (Early Breast Cancer Trialists' Collaborative Group 1990). Its efficacy in the treatment and prevention of ER-positive breast cancer was indisputably established 8 years later (Early Breast Cancer Trialists' Collaborative Group 1998a) in all age groups that were studied $(47 \%$ reduction in recurrence after 5 years and $26 \%$ reduction in mortality after 10 years). Accordingly, 5 years of tamoxifen is the standard adjuvant treatment for patients with hormone receptorpositive early breast cancer irrespective of age, menopausal status or tumor stage (Early Breast Cancer Trialists' Collaborative Group 1998a).

To date, results in the adjuvant setting, regarding aromatase inhibitors, are available only for anastrozole, which was tested in the world's largest individual cancer trial: the Anastrozole, Tamoxifen Alone or in Combination (ATAC) trial. Anastrozole achieved significantly longer disease-free survival than tamoxifen as a first-line adjuvant therapy at a median follow-up of 33 months (Baum et al. 2002). The efficacy re-analysis at a median follow-up of 47 months (Buzdar et al. 2003) confirmed the continued disease-free survival benefit in the anastrozoletreated group.

Letrozole is being investigated in several large adjuvant trials: the North-American Intergroup Trial and the Breast Cancer International Group trial (comparing tamoxifen for 2 years followed by letrozole for 3 years, versus letrozole for 2 years followed by tamoxifen for 3 years) (Goss 2001). No results have yet been presented from these two studies. The first results from an exemestane adjuvant trial reported that, after 2 to 3 years of tamoxifen therapy, switching to exemestane was more effective than continuing tamoxifen therapy for the remainder of the 5 years of treatment (Coombes et al. 2004). Significantly, an important recent study, designed to investigate the potential effects of continuing estrogen deprivation with letrozole after 5 years of tamoxifen treatment, indicated that the rate of disease-free survival was significantly higher in the letrozole-treated group than in the placebo-treated group (Goss et al. 2003). The above unexpected outcomes led to the early termination of the study after a median duration of follow-up of 2.4 years. However, in this limited period, no significant difference in overall survival was demonstrated. There is only fractional documentation on the effects of aromatase inhibitors in premenopausal patients; thus, such therapy is currently restricted to postmenopausal women.

The Early Breast Cancer Trialists' Collaborative Group (1996) has confirmed that in women (50 years of age), overall survival and recurrence-free survival significantly improved after ovarian ablation. Combination chemotherapy has also been found to substantially improve the long-term relapse-free and overall survival of both premenopausal and postmenopausal women up to the age of 70 years (Early Breast Cancer Trialists' Collaborative Group 1998b).

The availability of a treatment producing a reversible castration acceptable to many patients in the adjuvant setting and the evidence supporting an endocrine mechanism of cytotoxic chemotherapy in premenopausal patients led to the hypothesis that GnRH analogues could be of benefit in the treatment of hormonal-sensitive breast cancer. It has been indicated that a reversible castration over 2-3 years with a GnRH analogue is comparable in terms of disease-free and overall survival to treatment with six courses of cyclophosphamide, methotrexate and fluorouracil (CMF) chemotherapy (Boccardo et al. 2000, Castiglione-Gertsch et al. 2000) among premenopausal patients with hormone receptor-positive disease. Radiotherapy at the ovaries seems to produce a two-third reduction in local recurrence of breast cancer; however, the absolute benefit is diminished because of the disadvantage of permanent amenorrhea (Early Breast Cancer Trialists' Collaborative Group 2002, del Moral et al. 2002).

The hypothesis of combined endocrine treatment has been addressed in the ATAC trial. The combination arm with anastrozole plus tamoxifen did not show a better outcome than the tamoxifen-alone arm. In fact, as mentioned, the outcome was inferior to that in the anastrozole-alone arm. Furthermore, according to the findings of the Austrian Breast and Colorectal Cancer Study Group trial, there were no significant differences between the use of tamoxifen-alone versus tamoxifen plus aminoglutethimide for 5 years of treatment in postmenopausal women with early-stage breast cancer in terms of either disease-free or overall survival (Schmid et al. 2003).

\section{Efficacy of hormonal treatment in advanced disease}

As second-line therapy after tamoxifen for ER-positive metastatic breast cancer, all three aromatase inhibitors have been shown to be superior to progestin therapy because of their better safety profile and favorable impact on survival (Buzdar et al. 1998, Dombernowsky et al. 1998). In recent years, it has been found that aromatase inhibitors are superior to tamoxifen in the first-line treatment of advanced disease (Bonneterre et al. 2000). 
In an overview of trials comparing treatment with a GnRH analogue with or without tamoxifen among premenopausal patients with advanced disease, the patients treated with concurrent tamoxifen showed a significantly higher objective response rate and a longer progression-free and overall survival, compared with those treated with the GnRH analogue alone (Klijn et al. 2001). In women with metastatic disease and positive ERs, chemotherapy seems to act more efficaciously against rapidly progressing tumors (Wilcken et al. 2003).

Fulvestrant has been approved in the USA for the treatment of postmenopausal women with hormone receptor-positive metastatic breast cancer following progression on anti-estrogen therapy. Patients with hormonesensitive breast cancer who have responded to tamoxifen may receive additional benefit from a second endocrine agent (fulvestrant, megestrol acetate, aromatase inhibitors), following progression or relapse after tamoxifen therapy (Morris \& Wakeling 2002). Similar response rates and time to progression have been reported (Bross et al. 2002) in postmenopausal women with a previous response to endocrine therapy when an aromatase inhibitor or fulvestrant were administered.

\section{Mechanisms of action}

Tamoxifen appears to have both agonist and antagonist estrogenic actions in various organs and inhibits the growth of breast tumors by competitively antagonizing estrogen binding to its receptor. Tamoxifen decelerates the proliferation of breast cancer cells by inhibiting their progression from the G1 phase of the cell cycle and induces apoptosis. The cellular effect of the linkage of a SERM with the receptor is a complex procedure and depends on the specific isoform $(\alpha$ or $\beta$ ) of the receptor. Thus, SERMs act as an antagonist when combined with ER- $\beta$ but can also function as an agonist through ER- $\alpha$ (Hall \& McDonnell 1999). Moreover, a number of coregulator peptides which seem to interfere with the receptor's function, acting as either a positive or a negative regulator, have been discovered. The potential role of these proteins, both co-activators and corepressors, is still under investigation but they seem to modulate the biological responsiveness of the target cell of a SERM in various ways (Riggs \& Hartman 2003).

Among postmenopausal women, the agonistic action of the SERM raloxifene in bone has attracted much interest, especially after the early termination of the Women's Health Initiative (WHI), because of the reported elevated risk in breast cancer and the increased occurrence of cardiovascular events with the use of hormone replacement therapy (HRT) (Chlebowski et al. 2003, Wassertheil-Smoller et al. 2003). Although many questions posed by the above study remain unanswered, raloxifene appears to be a reasonable alternative in postmenopausal women for the prevention of osteoporosis. Raloxifene, beneficial to HRT because of its tissue selectivity, seems to act as an estrogen antagonist in breast cancer (Cummings et al. 1999). Preliminary results of the study of raloxifene and tamoxifen (STAR) trial will add much to our awareness of the potential use of raloxifene in the prevention of breast cancer (Vogel et al. 2002). However, to date, raloxifene is approved for postmenopausal osteoporosis in patients without a history of breast cancer, or in breast cancer patients only after their treatment, including adjuvant therapy, has been completed (raloxifene prescribing information (package insert) 1999; Eli Lilly and Co., Indianapolis, IN, USA). Aromatase inhibitors markedly suppress plasma estrogen levels in postmenopausal women by inhibiting or inactivating the enzyme aromatase. This enzyme is responsible for the conversion of androgenic substrates to estrogens (specifically, the synthesis of estrone from the preferred substrate androstendione and estradiol from testosterone) (Smith \& Dowsett 2003). The third-generation aromatase inhibitors can be classified with respect to their chemical structure as steroidal or non-steroidal agents. The two main members of non-steroidal aromatase inhibitors are letrozole and anastrozole.

Exemestane is an irreversible, steroidal, specific thirdgeneration aromatase inactivator. Maximal estrogen suppression occurs after the first 2-3 days of therapy and estrogen levels return to baseline in 10-14 days. Highly selective blockade of aromatase does not interfere with the production of other steroids (e.g. adrenal corticosteroids, aldosterone and androgens). Evidence suggests that tumor progression is not due to a loss of estrogen suppression but to newly developed tumor resistance, including acquired hypersensitivity of some tumor cells to estrogens. Differences in the mechanism of action in this class of agents may contribute to the apparent lack of cross-resistance between steroidal (e.g. exemestane) and non-steroidal (e.g. letrozole and anastrozole) aromatase inhibitors (Kvinnsland et al. 2000). So far, exemestane has been approved only for the treatment of postmenopausal women with recurrent breast cancer in deterioration after tamoxifen (Lonning 2000). Findings from ongoing studies will determine the role of exemestane in early breast cancer and its potential role in breast cancer prevention (Jones \& Jones 2000).

Excessive or inappropriate aromatase expression was demonstrated in adipose fibroblasts surrounding breast carcinoma. Intra-tumoral activity of aromatase in the majority of breast tumors is well established and such activity contributes substantially to intra-tumoral estrogen levels. It has been proved that anastrozole, letrozole 
and exemestane noticeably inhibit this action (Miller \& Dixon 2001). In conclusion, the relative clinical significance of the potential direct role of all the pharmacological agents used for adjuvant therapy in breast cancer on the intra-tumoral hormonal milieu remains unknown.

GnRH analogues suppress secretion of pituitary gonadotropins and this results in the reduction of estrogen production. These molecules bind to specific receptors consisting of seven transmembrane domains on pituitary gonadotropic cells, stimulating a rapid $\mathrm{Ca}^{2+}$ mobilization from internal stores. GnRH analogues differ from native GnRH in their 100- to 200-fold higher binding affinity to the receptors and in their pharmacokinetic parameters. GnRH agonists lead to an intense release of stored luteinizing hormone and follicle-stimulating hormone (the 'flare-up effect'), which results in a temporary increase of ovarian-produced estradiol, followed by a more prolonged decrease of pituitary hormone secretion (desensitization). On the other hand, recently introduced GnRH antagonists induce immediate reduction of gonadotropin levels, presenting a promising option in the goal of diminishing circulated estrogen (Kiesel et al. 2002). It is of interest that GnRH analogues, in addition to their essential action of suppressing the secretion of pituitary gonadotropins, might play other roles. Expression of GnRH receptors in both healthy (Kottler et al. 1997, Grundker et al. 2002) and cancer breast cells (Harris et al. 1991, Grundker et al. 2002) presume a possible autocrine/paracrine mechanism of the action of GnRH analogues in these tissues by modifying cell function(s). Stimulation of these receptors by GnRH analogues leads to activation of various intracellular mechanisms, which are different in normal and cancer cells. However, these potential anti-cancer properties of GnRH analogues are still hypothetical.

The development of fulvestrant as a selective antagonist of estrogen was based on the understanding that tamoxifen-like drugs are not devoid of estrogen-like actions and that their intrinsic partial agonist effects may have undesired consequences in various tissues. In contrast to the partial agonists, studies have demonstrated that multiple changes in ER function after fulvestrant treatment (i.e. impaired dimerization, increased turnover and disrupted nuclear localization) contribute to the blockade of estrogen action (Howell et al. 2000). Moreover, it is reported (Pink \& Jordan 1996) that fulvestrant markedly reduces cellular levels of ERs in pointed contrast to the stable or increased ER levels associated with tamoxifen.

Finally, alternative therapeutic approaches consist of the supplementary use of various chemotherapeutic regimens and occasionally radiotherapy, which act directly on ovaries, suppressing the production of estrogens. Combination of the above strategies tends to be the current state of the art in the issue of treating patients with ER-positive cancers even at early stages of the disease (Table 1).

\section{Skeletal effects}

Two isoforms of estrogenic receptors have been identified in bones: $\alpha$-receptors $(E R-\alpha)$, which are expressed mostly in the developing cortical bone, and $\beta$-receptors $(E R-\beta)$ which are expressed in the developing cancellous bone (Bord et al. 2001). Tamoxifen reduces bone demineralization due to its confirmed agonist estrogenic action (Love et al. 1994, Powles et al. 1996) and this is a disadvantage in premenopausal patients. Bone density was slightly improved in postmenopausal women who received tamoxifen for 2 years; however, almost half of this benefit was lost after 5 years of continuous administration, which is the usual duration of tamoxifen therapy. Regarding the fracture risk, the results of the available reports are conflicting (Riggs \& Hartman 2003). Anastrozole, by lowering the circulating estrogen levels, appears to be associated with a higher incidence of total and vertebral fractures $(5.9 \%$ and $0.7 \%$ respectively) than tamoxifen (3.7\% and $0.3 \%$ respectively) according to the results derived from the ATAC trial (Baum et al. 2002). It is of great interest that in the same study the reported risk for hip fractures was $0.4 \%$, irrespective of the agent administered. This could possibly be explained by the different concentrations of ERs in the various types of bones, which result in a different total effect of each regimen in vertebral bones and a similar effect in the hip region. In addition, aromatase inhibitors have been considered responsible for the clinical syndrome of polyarthralgia, which appears to be unrelated to increased bone resorption (ATAC trial). Arthralgia with similar features has been mentioned in cases of women during the postpartum period and in early menopause, when circulating estrogens are rapidly decreased. Based on this observation, it has been suggested that estrogen has a possible suppressive role in the progression of rheumatoid diseases (Wluka et al. 2000, Baum et al. 2002). In a short-term 3-month postmenopausal human volunteer experiment, exemestane or letrozole was administered daily at the usual anticancer doses of 25 and $2.5 \mathrm{mg}$ respectively to each of 20 women, and a placebo was given to 20 women representing a control group (Goss et al. 2002). Over this short time-period, bone biomarkers of formation and resorption were similar in the women given exemestane or placebo (Goss et al. 2002). In contrast, there was a sharp increase in bone turnover in those given letrozole over the same time-period. It has been assumed from studies in ovariectomized rats that bone metabolism is protected by the androgenicity of 
Table 1 Common hormonal treatment in ER-positive breast cancer

\begin{tabular}{|c|c|c|c|c|c|}
\hline Substance & Action & Dose & Current indication & $\begin{array}{l}\text { Promising but } \\
\text { preliminary results }\end{array}$ & $\begin{array}{l}\text { Future } \\
\text { directions }\end{array}$ \\
\hline Tamoxifen & $\begin{array}{l}\text { Antagonizing estrogen } \\
\text { binding to its receptor }\end{array}$ & 20 mg/day p.o. & $\begin{array}{l}\text { All stages of breast } \\
\text { cancer alone or in } \\
\text { combination with other } \\
\text { agents }\end{array}$ & & \\
\hline $\begin{array}{l}\text { Megestrol } \\
\text { acetate }\end{array}$ & Anti-estrogenic action & 160 mg/day p.o. & $\begin{array}{l}\text { Second-line therapy in } \\
\text { postmenopausal patients } \\
\text { with advanced breast } \\
\text { cancer previously } \\
\text { treated with tamoxifen }\end{array}$ & $\begin{array}{l}\text { Third-line therapy } \\
\text { after failure of } \\
\text { aminoglutethimide }\end{array}$ & \\
\hline Raloxifene & $\begin{array}{l}\text { Antagonizing estrogen } \\
\text { binding to its receptor }\end{array}$ & 60 mg/day p.o. & $\begin{array}{l}\text { Postmenopausal } \\
\text { osteoporosis }\end{array}$ & Chemoprevention & \\
\hline Anastrozole & $\begin{array}{l}\text { Non-steroidal } \\
\text { third-generation } \\
\text { aromatase inhibitor }\end{array}$ & 1 mg/day p.o. & $\begin{array}{l}\text { Postmenopausal women } \\
\text { with advanced disease } \\
\text { or in adjuvant therapy } \\
\text { (particularly if tamoxifen } \\
\text { is contraindicated) }\end{array}$ & $\begin{array}{l}\text { Neoadjuvant therapy } \\
\text { and chemoprevention }\end{array}$ & $\begin{array}{l}\text { Use in combination } \\
\text { with chemotherapy }\end{array}$ \\
\hline Letrozole & $\begin{array}{l}\text { Non-steroidal } \\
\text { third-generation } \\
\text { aromatase inhibitor }\end{array}$ & 2.5 mg/day p.o. & $\begin{array}{l}\text { Postmenopausal women } \\
\text { with advanced disease }\end{array}$ & $\begin{array}{l}\text { Continuing hormonal } \\
\text { therapy after } 5 \text { years } \\
\text { of tamoxifen } \\
\text { Neoadjuvant therapy } \\
\text { Chemoprevention } \\
\text { Preoperative therapy }\end{array}$ & $\begin{array}{l}\text { Use in combination } \\
\text { with chemotherapy }\end{array}$ \\
\hline Exemestane & $\begin{array}{l}\text { Steroidal-type } \\
\text { aromatase } \\
\text { inhibitor }\end{array}$ & 25 mg/day p.o. & $\begin{array}{l}\text { Second-line agent in } \\
\text { metastatic disease }\end{array}$ & First-line therapy & $\begin{array}{l}\text { Combination with } \\
\text { cytostatic agents } \\
\text { Neoadjuvant therapy }\end{array}$ \\
\hline Fulvestrant & 'Pure' anti-estrogen & $250 \mathrm{mg} / \mathrm{month}$ i.m. & $\begin{array}{l}\text { Second- or third-line } \\
\text { agent in postmenopausal } \\
\text { women with disease } \\
\text { progression following } \\
\text { anti-estrogen therapy }\end{array}$ & $\begin{array}{l}\text { Preoperative therapy } \\
\text { to downstage primary } \\
\text { breast cancer }\end{array}$ & $\begin{array}{l}\text { Replacement of } \\
\text { tamoxifen }\end{array}$ \\
\hline
\end{tabular}

exemestane and its metabolite 17-hydroexemestane (Goss et al. 2004).

It is possible that early-stage breast cancer patients could benefit from bisphosphonates by ameliorating the cancer treatment-related bone loss. Even more importantly, most women with newly diagnosed breast cancer are at risk of osteoporosis because of their age, and trends in adjuvant hormonal therapy indicate that osteoporosis will become a greater clinical problem in the future. Although raloxifene is approved for osteoporosis prevention and therapy, its use following 5 years of tamoxifen adjuvant therapy is not recommended. This is based on the fact that raloxifene and tamoxifen are similar agents and 10 years of tamoxifen use has been associated with more recurrences and deaths than 5 years of tamoxifen (Fisher et al. 2001).

Adequate information is currently available about the skeletal consequences of adjuvant chemotherapy. Chemotherapy-treated women who maintained ovarian function had normal bone mineral density (Headley et al. 1998), whilst a decrease in bone density was, as expected, reported in women with functional suppression of the ovaries (Shapiro et al. 2001). These women could be at risk for early development of osteoporosis and the use of bisphosphonates may be beneficial (Saarto et al. 1997, Partridge et al. 2001, Shapiro \& Recht 2001). However, the maintenance of bone density depends only in part on estrogen. The implementation of exercise and a multifaceted protocol of drug therapy for bone remodeling immediately following chemotherapy-induced treatment (bisphosphonates, calcium and vitamin D supplementation) are producing encouraging results (Twiss et al. 2001). The need for early bone mineral density assessments and close monitoring has therefore been suggested in this high-risk population of women. The American Society of Clinical Oncology (ASCO) guidelines published in November 2003 outline the appropriate measures for each risk-group category (Hilner et al. 2003). 
Because bisphosphonates have effectively reduced the development and progression of bone metastases in advanced breast cancer (Kanis et al. 1996, Theriault et al. 1999) current research has focused on bisphosphonates as an adjuvant therapy (Diel et al. 1998, Saarto et al. 2001, Powles et al. 2002). The trials conducted provide conflicting data on this potential role of bisphosphonates among patients with no evidence of distant metastases after definitive local surgery. Thus, starting bisphosphonates in women with only an abnormal bone scan but without evidence of bone destruction is not recommended and the presence or absence of bone pain should not be a factor in initiating bisphosphonates (ASCO; Hilner et al. 2003). Consequently, it remains uncertain as to whether bisphosphonates are beneficial and further investigation is needed to clarify whether bisphosphonates can influence the development of bone metastases and improve survival in early-stage breast cancer.

\section{Primary menopause and HRT in women with breast cancer}

Menopausal symptoms are an important source of morbidity in patients with breast cancer. The potential use of HRT in such patients is controversial, although recent reports have failed to confirm any increased risk of recurrence in women using HRT for breast cancer treatment, whereas the benefits in the quality of life reported were significant (Vassilopoulou-Sellin et al. 1999, O’Meara et al. 2001). However, existing clinical data do not yet suffice to evaluate the efficacy of this strategy (Cobleigh et al. 1994, Shapiro \& Recht 2001) and further randomized studies are needed to reassess the issue of HRT in women with breast cancer. A systematic review of 11 controlled and uncontrolled trials concluded that HRT has no significant effect on breast cancer recurrence; however, the reported findings were based on observational data subject to a variety of biases (Col et al. 2001). Until the WHI study was published, mortality due to breast cancer in HRT users was thought to be the same or even lower than in non-users and this has been attributed to earlier diagnosis and better prognosis. However, WHI reports revealed more advanced disease in HRT users (Chlebowski 2003, Wassertheil 2003), which is in contradiction to most published observational studies (Antoine et al. 2004).

Reasonably, HRT could be given in combination with tamoxifen in premenopausal women with increased levels of estrogens in order to eliminate the anti-estrogenic effect of tamoxifen (e.g. hot flushes). In addition, women with primary menopause due to chemotherapy could gain advantages from the supplementation of estrogens. About $5-10 \%$ of breast cancers are caused by an inherited mutation of either the BRCA1 or BRCA2 gene (Loman et al. 2001) and the great majority of these patients do not express ERs. Prophylactic mastectomy and oophorectomy are the most effective treatments in carriers of these mutations (Armes et al. 1999). This specific group of women could benefit from receiving HRT (Armstrong et al. 2004); however, available data are as yet insufficient (Riggs \& Hartman 2003).

The older age of patients and the duration of chemotherapy are positively correlated with increased risk of primary menopause. The time-course of menopause varies from 2 to 16 months from the beginning of chemotherapy. Permanent menopause, as a side-effect of $\mathrm{CMF}$, is more frequently reported compared with the combination of cyclophosphamide and doxorubicin. Whether the use of taxanes is associated with such an adverse effect on the patient's ovaries remains uncertain (Partridge et al. 2001, Shapiro \& Recht 2001). Reduction of libido has been mentioned in women undergoing adjuvant treatment, which seems to be related more often to the use of chemotherapy regimens rather than tamoxifen. Decreased libido in a patient with breast cancer seems to be a complex process which depends on an integration of potential mechanisms including neurotoxicity, estrogen reduction, impaired quality of life and possibly depression. Consequently, it is incorrect to assume that the observation mentioned above is solely an endocrine disorder (Ganz et al. 1998, Shapiro \& Recht 2001).

\section{The urogenital tract}

It is well known that lack of estrogens results in atrophy of the urogenital system and dispareunia. There is supporting evidence that estrogen replacement therapy in postmenopausal women is associated with increased risks of uterine cancer. Due to its local agonist role, tamoxifen is correlated with an approximately 2- to 2.5fold rise in the relative risk of endometrium cancer in the first 1 or 2 years of treatment and this risk is approximately quadrupled in trials of 5 years of tamoxifen administration (Early Breast Cancer Trialists' Collaborative Group 1998a, Fisher et al. 1998, Bergman et al. 2000). However, the agonist effect of tamoxifen in the uterus, with regard to the risk of endometrium cancer, is time, dose and age dependent (Fisher et al. 1998, Bergman et al. 2000, Baum et al. 2002, Chen et al. 2003). In this regard, vaginal bleeding, which is commonly observed in these women, requires further investigation (Fisher et al. 1998, Riggs \& Hartman 2003). In most cases, the detected tumor is not aggressive (i.e. low grade stage 1), and is rarely a sarcoma with a poor prognosis (Bergman et al. 2000, Baum et al. 2002). It has recently 
been suggested that tamoxifen differentially regulates human telomerase reverse transcriptase (hTERT) gene expression in breast and endometrial cancer cells, and this activity has been associated with the presence of an estrogen-sensitive element in the hTERT gene. The hypothesis of direct involvement of tamoxifen in the regulation of cancer cell growth may be associated with its opposite effects in the breast and uterus (Grundker et al. 2002). A reasonable approach for these patients is a routine pelvic examination and prompt evaluation of abnormal vaginal bleeding by endometrial biopsy.

\section{Cardiovascular effects}

SERMS mimicking estrogen actions reduce the level of low density lipoprotein cholesterol and increase high density lipoprotein levels, without increasing the concentration of triglycerides (Bruning et al. 1988, Saarto et al. 1996). In contrast, the estrogen-lowering effects of aromatase inhibitors have an adverse effect on blood lipids, according to a small, short-term study (Elisaf et al. 2001). The available data are insufficient to evaluate the long-term effects discussed.

The cumulative cardiovascular effect of tamoxifen seems to be related to inflammatory, thrombotic and antiatherogenic activities. Tamoxifen has been associated with increased relative risk of venus thromboembolism (1.5- to 3-fold rise), but the total risk remains small (Cutuli et al. 1995, Meier \& Jick 1998, Baum et al. 2002). On the other hand, analyses of individual trials have suggested that long-term adjuvant treatment with tamoxifen may result in substantial reduction of cardiac morbidity (Rutqvist \& Mattsson 1993).

The concurrent combination of chemotherapy and tamoxifen has been associated with an increased risk of thromboembolism when compared with tamoxifen administration alone (Saphner et al. 1991) among postmenopausal patients. Patients receiving anastrozole had a significantly lower incidence of venous thromboembolism compared with the patients receiving tamoxifen $(2.1 \%$ and $3.5 \%$ respectively) (Baum et al. 2002).

\section{Cognitive effects}

ER- $\alpha$ receptors are mainly located in the hypothalamus, while ER- $\beta$ receptors are distributed in almost the entire brain (hippocampus-amygdala) and thus are strongly associated with superior cerebral functions and memory. Several potential mechanisms have been proposed including: (a) accumulation of the production and secretion of neurotransmitters; (b) direct action on the nervous cells and stabilization of the structure of cell membrane; (c) prevention of cerebrovascular ischemia; and (d) alteration of the serum lipoproteinic profile. Experimental studies on animals have shown that estrogen promotes both the enlargement and the maturation of the dendritic spines of nervous cells located in the hypothalamus and hippocampus.

Additionally, an increase in the number of synapses has been observed in sections of the brain which are topographically associated with learning. It has been suggested that estrogen affects memory-linked processes in postmenopausal women by altering brain activation patterns in specific brain regions (Shaywitz et al. 1999). Another study has indicated that the use of estrogen in postmenopausal women may delay the onset and decrease the risk of Alzheimer's disease (Tang et al. 1996). Despite the above findings in postmenopausal women, it remains unknown as to whether the status of diminished estrogen levels after the use of adjuvant treatment translates to clinical impairment.

To date, studies focused on the long-term outcomes of tamoxifen have not furnished sufficient information to enhance our knowledge about its impact in the cognition and behavior of the treated patients (Winer et al. 2002). A double-blind randomized trial (Multiple Outcomes of Raloxifene Evaluation (MORE) study), which is currently investigating the multiple outcomes of another SERM, raloxifene, is expected to clarify several issues. Local estrogen biosynthesis modified by aromatase activity in the brain may be important in the regulation of various cognitive and hypothalamic functions, but little is known about the clinical expression of this hypothesis. However, improvement in cognitive function (based on the European Organisation for Research and Treatment of Cancer Quality of Life Questionnaire (EORTC) QLQC30 quality-of-life test) of patients treated with retrozole has been reported (Phillips \& Bernhard 2003).

Regarding adjuvant chemotherapy, several authors have attempted to estimate its potential side-effects on memory, concentration and attention by using questionnaires and psychological tests (Schagen et al. 1999, Partridge et al. 2001). However, some of the examined patients were co-treated with tamoxifen, thus making it difficult to reach a conclusion. It is of interest that these studies failed to determine further cognitive impairment in the subgroup of patients who received additional tamoxifen (Schagen et al. 1999). Moreover, approximately onethird of the examined women complained of cognitive disorders, a factor which failed to be recorded in the tests performed. Nevertheless, it is clear that the severity of symptoms positively correlates with the use of increased drug doses (van Dam et al. 1998, Schagen et al. 1999, Partridge et al. 2001). The role of taxanes in the neurotoxicity of peripheral nerves has been well established, but their role in the central nervous system has yet 
to be investigated (Shapiro \& Recht 2001). In conclusion, the observed discrepancy between subjective symptoms and objective findings in several studies may have resulted not only from the insufficient objectiveness of the methods used, but also from individual variations in the way the patients were mentally and psychologically influenced during the painful procedure of chemotherapy (Kattlove \& Winn 2003).

\section{Hot flushes}

It has been confirmed that the use of tamoxifen increases hot flushes in women with breast cancer (17\% vs $7.5 \%$ of the placebo-treated group), but this adverse effect seems to be eliminated in the late postmenopausal period (Riggs \& Hartman 2003). Initial results of the ATAC trial have shown a comparative risk for the appearance of hot flushes with anastrozole and tamoxifen $(34.3 \%$ and $39 \%$ respectively) (Baum et al. 2002). In women unable or unwilling to take hormonal therapies such as in breast cancer (Biglia et al. 2003), several non-hormonal alternatives have been proposed, namely clonidine (an $\alpha 2$ presynaptic adrenergic agonist), venlafaxine, paroxetine and gabapentin (selective serotonin reuptake inhibitors) (Pandya et al. 2000). Many of the women studied were taking concurrent tamoxifen and all of these agents have demonstrated efficacy in reducing hot flushes (Sicat \& Brokaw 2004). Tamoxifen is converted to 4-hydroxytamoxifen and other active metabolites by cytochrome P450 enzymes and this conversion is reduced by the coadministration of a selective serotonin reuptake inhibitor (Stearns et al. 2003). Thus, hot flushes in breast cancer survivors should no longer be considered untreatable as there are pharmacologic treatments available that can help alleviate this problem.

\section{Weight gain}

Aromatase expression in adipose tissue primarily accounts for the extraglandular (peripheral) formation of estrogen and increase in body weight in obese postmenopausal women. From this viewpoint, obesity has been associated with an increase in the recurrence of breast cancer, and thus it is considered as a potential risk factor in the progression of the disease (Camoriano et al. 1990, Partridge et al. 2001, Shapiro \& Recht 2001). Premenopausal women undergoing a prolonged therapeutic regime and those receiving prednisone are the most likely to gain weight. Appearance of symptoms of depression and a parallel mild increase in body weight has been associated with tamoxifen, but the reported cases are few. Regarding chemotherapy, the usual weight increase is $2-6 \mathrm{~kg}$ and is milder with doxorubicin and cyclophosphamide use than with CMF treatment. Possible causes are suggested as being the reduction of physical exercise, increased food intake, primary ovarian failure and possible alterations in the basic metabolism (DemarkWahnefried et al. 1993, 1997).

\section{New breast cancer events}

Early findings on the use of SERMs (tamoxifen and raloxifene) as a prophylaxis against ER-positive breast cancer have demonstrated hopeful, though preliminary, results (Cuzick et al. 2003, Early Breast Cancer Trialists' Collaborative Group 1998a). Evidence based on the National Surgical Adjuvant Breast and Bowel Project (NSABP) has been developed for the use of tamoxifen as a risk-reducing agent in women at high-risk for breast cancer (49\% decrease among high-risk women) (Fisher et al. 1998). This use of tamoxifen was supported by European tamoxifen trials which, however, included both high- and low-risk women (Cuzick et al. 2003). However, it is crucial to identify the subgroup of high-risk healthy women for whom the risk/benefit ratio is sufficiently positive. It is suggested that maximal clinical benefit and minimal side-effects could be derived from the preventive use of tamoxifen in younger premenopausal women, who are less likely to have thromboembolic sequelae and uterine cancer (Chlebowski et al. 2002). The MORE trial, which evaluated the use of raloxifene to prevent osteoporosis, found (after 40 months of followup) that the risk of invasive breast cancer decreased by 76\% (Cummings et al. 1999). Among postmenopausal women, some investigators reported that measurements of estradiol level could help to identify women belonging to the potential 'high-risk' group, who may benefit most from the use of raloxifene (Cummings et al. 2002). In 1999, the NSABP initiated a second study (which is currently under way), the STAR trial, in order to evaluate the use of raloxifene, by comparison with tamoxifen, as a potential preventive agent in breast cancer. This study was designed to recruit approximately 19000 women and will investigate the efficacy of both regimens in reducing the incidence of primary breast cancer in high-risk healthy women (Vogel et al. 2002).

Another major issue in the topic of ER-positive breast cancer is the optimal management of postmenopausal patients who have completed the classical 5 years of adjuvant tamoxifen therapy. An important recent study, designed to investigate the potential effects of continuing estrogen deprivation with an aromatase inhibitor (letrozole), indicated that the rate of disease-free survival was significantly higher in the letrozole-treated group than in the placebo-treated group (Goss et al. 2003). Distant metastasis, ipsilateral recurrences and new contra-lateral 
Endocrine-Related Cancer (2004) 11 523-535

Table 2 Side-effects of available agents in adjuvant therapy of breast cancer

\begin{tabular}{|c|c|c|c|c|c|c|c|c|c|}
\hline Side-effect & Tamoxifen & Raloxifene & $\begin{array}{l}\text { Megestrol } \\
\text { acetate }\end{array}$ & Fulvestrant & Letrozole & Anastrozole & Exemestane & $\begin{array}{c}\text { GnRH } \\
\text { analogues }\end{array}$ & Chemotherapy \\
\hline Hot flushes & ++ & ++ & + & + & + & + & $\mathrm{N} / \mathrm{A}$ & + & + \\
\hline Uterine discharge & + & $\leftrightarrow$ & + & $\leftrightarrow$ & $\leftrightarrow$ & $\leftrightarrow$ & $\mathrm{N} / \mathrm{A}$ & - & $\leftrightarrow$ \\
\hline Endometrial cancer & + & $\leftrightarrow$ & $\mathrm{N} / \mathrm{A}$ & $?$ & $\leftrightarrow$ & $\leftrightarrow$ & $\mathrm{N} / \mathrm{A}$ & $?$ & $\leftrightarrow$ \\
\hline $\begin{array}{l}\text { Prevention in new } \\
\text { breast cancer events }\end{array}$ & + & + & $\mathrm{N} / \mathrm{A}$ & $?$ & + & + & $\mathrm{N} / \mathrm{A}$ & $\mathrm{N} / \mathrm{A}$ & $?$ \\
\hline Thromboembolism & ++ & $\leftrightarrow$ & + & $\leftrightarrow$ & $\leftrightarrow$ & $\leftrightarrow$ & $\mathrm{N} / \mathrm{A}$ & $\leftrightarrow$ & $t^{2}$ \\
\hline Arthralgia & $\leftrightarrow$ & $\leftrightarrow$ & $\mathrm{N} / \mathrm{A}$ & + & ++ & ++ & $\leftrightarrow$ & $\leftrightarrow$ & $\leftrightarrow$ \\
\hline Bone density & + & ++ & $\mathrm{N} / \mathrm{A}$ & $?$ & - & - & $?$ & - & $?$ \\
\hline Cognitive function & $?$ & $\mathrm{~N} / \mathrm{A}$ & $\mathrm{N} / \mathrm{A}$ & $\mathrm{N} / \mathrm{A}$ & $\mathrm{N} / \mathrm{A}$ & $\mathrm{N} / \mathrm{A}$ & $\mathrm{N} / \mathrm{A}$ & $\mathrm{N} / \mathrm{A}$ & $?$ \\
\hline Weight gain & + & $?$ & ++ & + & $\leftrightarrow$ & $\leftrightarrow$ & $\mathrm{N} / \mathrm{A}$ & $\mathrm{N} / \mathrm{A}$ & + \\
\hline Ovarian suppression & $\leftrightarrow$ & $\leftrightarrow$ & $\leftrightarrow$ & $\leftrightarrow$ & $\leftrightarrow$ & $\leftrightarrow$ & $\leftrightarrow$ & $+{ }^{1}$ & ++ \\
\hline
\end{tabular}

+ , drug increases this effect; -, drug decreases this effect; $\leftrightarrow$, no change; N/A, no data available; ?, conflicting or insufficient data;

$+{ }^{1}$, preserve ovarian function from chemotherapy-induced infertility; $+^{2}$, attenuated by concurrent treatment with tamoxifen.

breast cancers were implicated as breast cancer events. The above unexpected outcomes led to the early termination of the study after a median duration of follow-up of 2.4 years. However, in this limited period, no significant difference in overall survival was demonstrated (Goss et al. 2003).

\section{Conclusions}

Side-effects of adjuvant therapy for breast cancer must be taken into account when planning therapy (Table 2), but the clinical experience of many decades has shown that the benefits far outweigh the risks. In conclusion, patients receiving anastrozole have a significantly lower incidence of hot flushes, vaginal bleeding, vaginal discharge and venous thromboembolism, and a significantly higher incidence of musculoskeletal symptoms and fractures than those receiving tamoxifen. However, tamoxifen remains the 'golden standard' in adjuvant early ERpositive breast cancer treatment. Preliminary findings from the use of aromatase inhibitors are promising, but longer follow-up investigations are required before a final 'benefit vs risk' assessment can be made for this endocrine option. Use of anastrozole has not yet been recommended as a first-line therapy in premenopausal women (American Society of Clinical Oncology Technology Assessment (Winer et al. 2002)), but anastrozole treatment is currently a useful alternative, especially in patients who do not tolerate tamoxifen.

\section{References}

Antoine C, Liebens F, Carly B, Pastijn A \& Rozenberg S 2004 Influence of HRT on prognostic factors for breast cancer: a systematic review after the Women's Health Initiative trial. Human Reproduction 19 741-756.
Armes JE, Trute L, White D, Southey MC, Hammet F, Tesoriero A, Hutchins AM, Dite GS, McCredie MR, Giles GG, Hopper JL \& Venter DJ 1999 Distinct molecular pathogenesis of early-onset breast cancer in mutation carriers: a populationbased study. Cancer Research 59 2011-2017.

Armstrong K, Schwartz JS, Randall T, Rubin SC \& Weber B 2004 Hormone replacement therapy and life expectancy after prophylactic ophorectomy in women with mutations: a decision analysis. Journal of Clinical Oncology 22 1045-1054.

Baum M, Budzar AU, Cuzick J, Forbes J, Houghton JH, Klijn JG \& Sahmoud T 2002 Anastrozole alone or in combination with tamoxifen versus tamoxifen alone for adjuvant treatment for postmenopausal women with early breast cancer: first results of the ATAC randomized trial. Lancet 359 2131-2139.

Bergman L, Beelen ML, Gallee MP, Hollema H, Benraadt J \& van Leeuwen FE 2000 Risk and prognosis of endometrial cancer after tamoxifen for breast cancer. Lancet 356 881-887.

Biglia N, Cozzarella M, Cacciari F, Ponzone R, Roagna R, Maggiorotto F \& Sismondi P 2003 Menopause after breast cancer: a survey on breast cancer survivors. Maturitas $\mathbf{4 5}$ 29-38.

Boccardo F, Rubagotti A, Amoroso D, Mesiti M, Romeo D, Sismondi P, Giai M, Genta F, Pacini P, Distante V, Bolognesi A, Aldrighetti D \& Farris A 2000 Cyclophosphamide, methotrexate, and fluorouracil versus tamoxifen plus ovarian suppression as adjuvant treatment of ER-positive pre-/ perimenopausal breast cancer patients: results of the Italian Breast Cancer Adjuvant Study Group 02 randomized trial. Journal of Clinical Oncology 18 2718-2727.

Bonneterre J, Thurlimann B, Robertson JF, Krzakowski M, Mauriac L, Koralewski P, Vergote I, Webster A, Steinberg M \& von Euler M 2000 Anastrozole versus tamoxifen as first-line therapy for advanced breast cancer in 668 postmenopausal women: results of the Tamoxifen or Arimidex Randomized Group Efficacy and Tolerability study. Journal of Clinical Oncology 18 3748-3757.

Bord S, Horner A, Beavan S \& Compston J 2001 Estrogen receptors $\alpha$ and $\beta$ are differentially expressed in developing human bone. Journal of Clinical Endocrinology and Metabolism 86 2309-2314. 
Bross PF, Cohen MH, Williams GA \& Pazdur R 2002 FDA drug approval summaries: fulvestrant. The Oncologist 7 477-480.

Bruning PF, Bonfrer JMG, Hart AA, De Jong-Bakker M, Linders D, van Loon J \& Nooyen WJ 1988 Tamoxifen, serum lipoproteins and cardiovascular risk. British Journal of Cancer 58 497-499.

Buzdar AU, Jonat W, Howell A, Jones SE, Blomqvist CP, Vogel CL, Eiermann W, Wolter JM, Steinberg M, Webster A \& Lee D 1998 Anastrozole versus megestrol acetate in the treatment of postmenopausal women with advanced breast carcinoma: results of a survival update based on a combined analysis of data from two mature phase III trials. Arimidex Study Group. Cancer 83 1142-1152.

Buzdar AU on behalf of the ATAC Trialists' Group 2003 The ATAC ('Arimidex', Tamoxifen, Alone or in Combination) trial in postmenopausal women with early breast cancer updated efficacy results based on median follow-up of 47 months. Breast Cancer Research and Treatment 77295.

Camoriano JK, Loprinzi CL, Ingle JN, Therneau TM, Krook JE \& Veeder MH 1990 Weight change in women treated with adjuvant therapy or observed following mastectomy for nodepositive breast cancer. Journal of Clinical Oncology $\mathbf{8}$ 1327-1334.

Castiglione-Gertsch M, Gelber RD, O'Neill A, Coates AS \& Goldhirsch A 2000 Systemic adjuvant treatment for premenopausal node-negative breast cancer. The International Breast Cancer Study Group. European Journal of Cancer 36 549-550.

Chen P, Yang CC, Chen YJ \& Wang PH 2003 Tamoxifeninduced endometrial cancer. European Journal of Gynaecological Oncology 24 135-137.

Chlebowski RT, Col N, Winer EP, Collyar DE, Cummings SR, Vogel VG, Burstein HJ, Eisen A, Lipkus I \& Pfister DG 2002 American Society of Clinical Oncology Breast Cancer Technology Assessment Working Group. American Society of Clinical Oncology technology assessment of pharmacologic interventions for breast cancer risk reduction including tamoxifen, raloxifene, and aromatase inhibition. Journal of Clinical Oncology 20 3328-3343.

Chlebowski RT, Hendrix SL, Langer RD, Stefanick ML, Gass M, Lane D, Rodabough RJ, Gilligan MA, Cyr MG, Thomson CA, Khandekar J, Petrovitch H \& McTiernan A 2003 Influence of estrogen plus progestin on breast cancer and mammography in healthy postmenopausal women: the Women's Health Initiative Randomized Trial. Journal of the American Medical Association 289 3243-3253.

Cobleigh MA, Nortock FE, Oleske DM \& Starr A 1994 Estrogen replacement therapy in breast cancer survivors: a time for change. Journal of the American Medical Association 272 $540-545$.

Col NF, Hirota LK, Orr RK, Erban JK, Wong JB \& Lau J 2001 Hormone replacement therapy after breast cancer: a systematic review and quantitative assessment of risk. Journal of Clinical Oncology 19 2357-2363.

Coombes RC, Hall E, Gibson LJ, Paridaens R, Jassem J, Delozier T, Jones SE, Alvarez I, Bertelli G, Ortmann O, Coates AS, Bajetta E, Dodwell D, Coleman RE, Fallowfield LJ, Mickiewicz E, Andersen J, Lonning PE, Cocconi G, Stewart A, Stuart N, Snowdon CF, Carpentieri M, Massimini
G \& Bliss JM 2004 A randomized trial of exemestane after two to three years of tamoxifen therapy in postmenopausal women with primary breast cancer. New England Journal of Medicine 350 1081-1092.

Cummings SR, Eckert S, Krueger KA, Grady D, Powles TJ, Cauley JA, Norton L, Nickelsen T, Bjarnason NH, Morrow M, Lippman ME, Black D, Glusman JE, Costa A \& Jordan VC 1991 The effect of raloxifene on risk of breast cancer in postmenopausal women: results from the MORE randomized trial. Journal of the American Medical Association 281 2189-2197.

Cummings SR, Duong T, Kenyon E, Cauley JA, Whitehead M \& Krueger KA 2002 Multiple Outcomes of Raloxifene Evaluation (MORE) Trial. Serum estradiol level and risk of breast cancer during treatment with raloxifene. Journal of the American Medical Association 287 216-220.

Cutuli B, Petit JC, Fricker JP, Schumacher C, Velten M \& Abecassis J 1995 Thromboembolic accidents in postmenopausal patients with adjuvant treatment by tamoxifen. Frequency, risk factors and prevention possibilities. Bulletin du Cancer 82 51-56.

Cuzick J, Powles T, Veronesi U, Forbes J, Edwards R, Ashley S \& Boyle P 2003 Overview of the main outcomes in breastcancer prevention trials. Lancet 361 296-300.

van Dam FS, Schagen SB, Muller MJ, Boogerd W, van der Wall E, Droogleever Fortuyn ME \& Rodenhuis S 1998 Impairment of cognitive function in women receiving adjuvant treatment for high-risk breast cancer: high-dose versus standard-dose chemotherapy. Journal of the National Cancer Institute $\mathbf{9 0}$ 210-218.

Demark-Wahnefried W, Winer EP \& Rimer BK 1993 Why women gain weight with adjuvant chemotherapy for breast cancer. Journal of Clinical Oncology 11 1418-1429.

Demark-Wahnefried W, Hars V, Conaway MR, Havlin K, Rimer BK, McElveen G \& Winer EP 1997 Reduced rates of metabolism and decreased physical activity in breast cancer patients receiving adjuvant chemotherapy. American Journal of Clinical Nutrition 65 1495-1501.

Diel IJ, Solomayer EF, Costa SD, Gollan C, Goerner R, Wallwiener D, Kaufmann M \& Bastert G 1998 Reduction in new metastases in breast cancer with adjuvant clodronate treatment. New England Journal of Medicine 339 357-363.

Doisneau-Sixou SF, Sergio CM, Carroll JS, Hui R, Musgrove EA \& Sutherland RL 2003 Estrogen and antiestrogen regulation of cell cycle progression in breast cancer cells. Endocrine-Related Cancer 10 179-186.

Dombernowsky P, Smith I, Falkson G, Leonard R, Panasci L, Bellmunt J, Bezwoda W, Gardin G, Gudgeon A, Morgan M, Fornasiero A, Hoffmann W, Michel J, Hatschek T, Tjabbes T, Chaudri HA, Hornberger U \& Trunet PF 1998 Letrozole, a new oral aromatase inhibitor for advanced breast cancer: double-blind randomized trial showing a dose effect and improved efficacy and tolerability compared with megestrol acetate. Journal of Clinical Oncology 16 453-461.

Early Breast Cancer Trialists' Collaborative Group 1990 A Systematic Overview of All Available Randomized Trials of Adjuvant Endocrine and Cytotoxic Therapy, pp 1-207. Oxford: Oxford University Press. 
Early Breast Cancer Trialists' Collaborative Group 1996 Ovarian ablation in early breast cancer: overview of the randomised trials. Lancet 348 1189-1196.

Early Breast Cancer Trialists' Collaborative Group 1998 a Tamoxifen for early breast cancer: an overview of the randomized trials. Lancet 351 1451-1467.

Early Breast Cancer Trialists' Collaborative Group 1998 b Polychemotherapy for early breast cancer: an overview of the randomised trials. Lancet 352 930-942.

Early Breast Cancer Trialists' Collaborative Group 2002 Radiotherapy for early breast cancer (Cochrane Review). In Cochrane Database of Systematic Reviews CD003647.

Elisaf MS, Bairaktari ET, Nicolaides C, Kakaidi B, Tzallas CS, Katsaraki A \& Pavlidis NA 2001 Effect of letrozole on the lipid profile in postmenopausal women with breast cancer. European Journal of Cancer 37 1510-1513.

Fisher B, Constantino JP, Wicherman DL, Redmond CK, Kavanah M, Cronin WM, Vogel IV, Robidoux A, Dimitrov N, Atkins J, Daly M, Wieand S, Tan-Chiu E, Ford L \& Wolmark N 1998 Tamoxifen for prevention of breast cancer: report of the National Surgical Adjuvant Breast and Bowel Project P-1 Study. Journal of the National Cancer Institute 90 1371-1388.

Fisher B, Dignam J, Bryant J \& Wolmark N 2001 Five versus more than five years of tamoxifen for lymph node-negative breast cancer: updated findings from the National Surgical Adjuvant Breast and Bowel Project B-14 randomized trial. Journal of the National Cancer Institute 93 684-690.

Ganz PA, Rowland JH, Meyerowitz BE \& Desmond KA 1998 Impact of different adjuvant therapy strategies on quality of life in breast cancer. Recent Results in Cancer Research $\mathbf{1 5 2}$ 396-411.

Goss PE 2001 Preliminary data from ongoing adjuvant aromatase inhibitor trials. Clinical Cancer Research 7 4397-4401.

Goss PE, Thomsen T, Banke-Bochita J, Lowery C \& Asnis A 2002 A randomized, placebo-controlled, explorative study to investigate the effect of low estrogen plasma levels on markers of bone turnover in healthy postmenopausal women during the 12-week treatment with exemestane or letrozole.

San Antonio Breast Cancer Symposium 11-14 December (Abstract).

Goss PE, Ingle JN, Martino S, Robert NJ, Muss HB, Piccart MJ, Castiglione M, Tu D, Shepherd LE, Pritchard KI, Livingston RB, Davidson NE, Norton L, Perez EA, Abrams JS, Therasse P, Palmer MJ \& Pater JL 2003 A randomized trial of letrozole in postmenopausal women after five years of tamoxifen therapy for early-stage breast cancer. New England Journal of Medicine 349 1793-1802.

Goss PE, Qi S, Josse RG, Pritzker KP, Mendes M, Hu H, Waldman SD \& Grynpas MD 2004 The steroidal aromatase inhibitor exemestane prevents bone loss in ovariectomized rats. Bone 34 384-392.

Grundker C, Gunther AR, Westphalen S \& Emons G 2002 Biology of the gonadotropin-releasing hormone system in gynecological cancers. European Journal of Endocrinology 146 $1-14$.

Hall JM \& McDonnell DP 1999 The estrogen receptor betaisoform (ERbeta) of the human estrogen receptor modulates
ERalpha transcriptional activity and is a key regulator of the cellular response to estrogens and antiestrogens.

Endocrinology 140 5566-5578.

Harris N, Dutlow C, Eidne K, Dong KW, Roberts J \& Millar R 1991 Gonadotropin-releasing hormone (GnRh) gene expression in MDA-MB-231 and ZR-75-71 breast carcinoma cell lines. Cancer Research 51 2577-2581.

Headley JA, Theriault RL, LeBlanc AD, Vassilopoulou-Sellin R \& Hortobagyi GN 1998 Pilot study of bone mineral density in breast cancer patients treated with adjuvant chemotherapy. Cancer Investigation 16 6-11.

Hilner BE, Ingle JN, Chelbowski RT, Gralow J, Yee GC, Janjan NA, Cauley JA, Blumenstein BA, Albain KS, Lipton A \& Brown S 2003 American Society of Clinical Oncology 2003 Update on the role of bisphosphonates and bone health issues in women with breast cancer. Journal of Clinical Oncology 21 4042-4057.

Howell A, Osborne CK, Morris C \& Wakeling A $2000{ }^{3}$ ICI 182,780 (Faslodex ${ }^{\mathrm{TM}}$ ). Development of a novel, pure antiestrogen. Cancer 89 817-825.

Jones SA \& Jones SE 2000 Exemestane: a novel aromatase inactivator for breast cancer. Clinical Breast Cancer 1 211-216.

Kanis JA, Powles T, Paterson AH, McCloskey EV \& Ashley S 1996 Clodronate decreases the frequency of skeletal metastases in women with breast cancer. Bone 19 663-667.

Kattlove H \& Winn RJ 2003 Ongoing care of patients after primary treatment for their cancer. CA: A Cancer Journal for Clinicians 53 172-196.

Kiesel LA, Rody A, Greb RR \& Szilagyi A 2002 Clinical use of GnRH analogues. Clinical Endocrinology 56 677-687.

Klijn JG, Blamey RW, Boccardo F, Tominaga T, Duchateau L \& Sylvester R 2001 Combined tamoxifen and luteinizing hormone-releasing hormone (LHRH) agonist versus LHRH agonist alone in premenopausal advanced breast cancer: a meta-analysis of four randomized trials. Journal of Clinical Oncology 19 343-353.

Kottler ML, Starzec A, Carre MC, Lagarde JP, Martin A \& Counis R 1997 The genes for gonadotropin-releasing hormone $(\mathrm{GnRh})$ and its receptor are expressed in human breast with fibrocystic disease and cancer. International Journal of Cancer 71 595-599.

Kvinnsland S, Anker G, Dirix LY, Bonneterre J, Prove AM, Wilking N, Lobelle JP, Mariani O, di Salle E, Polli A \& Massimini G 2000 High activity and tolerability demonstrated for exemestane in postmenopausal women with metastatic breast cancer who had previously failed on tamoxifen treatment. European Journal of Cancer 36 976-982.

Loman N, Johannsson O, Kristoffersson U, Olsson H \& Borg A 2001 Family history of breast and ovarian cancers and BRCA1 and BRCA2 mutations in a population-based series of early-onset breast cancer. Journal of the National Cancer Institute 93 1215-1223.

Lonning PE 2000 Exemestane in breast cancer: current status and future directions. Clinical Breast Cancer 1 (Suppl 1) 28-33.

Love RR, Barden HS, Mazess RB, Epstein S \& Chappell RJ 1994 Effect of tamoxifen on lumbar spine bone mineral density in postmenopausal women after 5 years. Archives of Internal Medicine 154 2585-2588. 
Meier CR \& Jick H 1998 Tamoxifen and risk of idiopathic venous thromboembolism. British Journal of Clinical Pharmacology 45 608-612.

Miller WR \& Dixon JM 2001 Local endocrine effects of aromatase inhibitors within the breast. Journal of Steroid Biochemistry and Molecular Biology 79 93-102.

del Moral R, Lopez ME, Nunez MI, Oliver FJ, Valenzuela MT, Villalobos M \& Ruiz de Almodovar JM 2002 Interactions between radiotherapy and endocrine therapy in breast cancer. Endocrine-Related Cancer 9 197-205.

Morris C \& Wakeling A 2002 Fulvestrant ('Faslodex') — a new treatment option for patients progressing on prior endocrine therapy. Endocrine-Related Cancer 9 267-276.

O'Meara ES, Rossing MA, Daling JR, Elmore JG, Barlow WE \& Weiss NS 2001 Hormone replacement therapy after a diagnosis of breast cancer in relation to recurrence and mortality. Journal of the National Cancer Institute 93 754-762.

Pandya KJ, Raubertas RF, Flynn PJ, Hynes HE, Rosenbluth RJ, Kirshner JJ, Pierce HI, Dragalin V \& Morrow GR 2000 Oral clonidine in postmenopausal patients with breast cancer experiencing tamoxifen-induced hot flushes: a University of Rochester Cancer Center Community Clinical Oncology Program study. Annals of Internal Medicine $\mathbf{1 3 2}$ 788-793.

Partridge A, Burnstein HJ \& Winer EP 2001 Side effects of chemotherapy and combined chemohormonal therapy in women with early-stage breast cancer. Journal of the National Cancer Institute Monographs 30 135-142.

Paterson R \& Russel MH 1959 Clinical trials in malignant disease: part II. Breast cancer: value of irradiation of the ovaries. Journal of the Faculty of Radiology 10 130-133.

Phillips KA \& Bernhard J 2003 Adjuvant breast cancer treatment and cognitive function: current knowledge and research directions. Journal of the National Cancer Institute $\mathbf{9 5}$ 190-197.

Pink JJ \& Jordan VC 1996 Models of estrogen receptor regulation by estrogens and antiestrogens in breast cancer cell lines. Cancer Research 56 2321-2330.

Powles TJ, Hickish T, Kanis JA, Tidy A \& Ashley S 1996 Effect of tamoxifen on bone mineral density measured by dualenergy x-ray absorptiometry in healthy premenopausal and postmenopausal women. Journal of Clinical Oncology 14 78-84.

Powles T, Paterson S, Kanis JA, McCloskey E, Ashley S, Tidy A, Rosenqvist K, Smith I, Ottestad L, Legault S, Pajunen M, Nevantaus A, Mannisto E, Suovuori A, Atula S, Nevalainen J \& Pylkkanen L 2002 Randomized, placebo-controlled trial of clodronate in patients with primary operable breast cancer. Journal of Clinical Oncology 20 3219-3224.

Riggs BL \& Hartman LC 2003 Selective estrogen-receptor modulators - mechanisms of action and application to clinical practice. New England Journal of Medicine $\mathbf{3 4 8}$ 618-629.

Rutqvist LE \& Mattsson A 1993 Cardiac and thromboembolic morbidity among postmenopausal women with early-stage breast cancer in a randomized trial of adjuvant tamoxifen. The Stockholm Breast Cancer Study Group. Journal of the National Cancer Institute 85 1398-1406.
Saarto T, Blomqvist C, Ehnholm C, Taskinen MR \& Elomaa I 1996 Antiatherogenic effects of adjuvant antiestrogens: a randomized trial comparing the effects of tamoxifen and toremifene on plasma lipid levels in postmenopausal women with node-positive breast cancer. Journal of Clinical Oncology 14 429-433.

Saarto T, Blomqvist C, Valimaki M, Makela P, Sarna S \& Elomaa F 1997 Chemical castration induced by adjuvant cyclophosphamide, methotrexate, and fluorouracil chemotherapy causes rapid bone loss and is reduced by clodronate. Journal of Clinical Oncology 15 1341-1347.

Saarto T, Blomqvist C, Virkkunen P \& Elomaa I 2001 Adjuvant clodronate treatment does not reduce the frequency of skeletal metastases in node-positive breast cancer patients: 5 -year results of a randomized controlled trial. Journal of Clinical Oncology 19 10-17.

Saphner T, Tormey DC \& Gray R 1991 Venous and arterial thrombosis in patients who received adjuvant therapy for breast cancer. Journal of Clinical Oncology 9 286-294.

Schagen S, van Dam FS, Muller MJ, Boogerd W, Lindeboom J \& Bruning PF 1999 Cognitive deficits after postoperative adjuvant chemotherapy for breast carcinoma. Cancer $\mathbf{8 5}$ 640-650.

Schmid M, Jakesz R, Samonigg H, Kubista E, Gnant M, Menzel C, Seifert M, Haider K, Taucher S, Mlineritsch B, Steindorfer P, Kwasny W, Stierer M, Tausch C, Fridrik M, Wette V, Steger G \& Hausmaninger H 2003 Randomized trial of tamoxifen versus tamoxifen plus aminoglutethimide as adjuvant treatment in postmenopausal breast cancer patients with hormone receptor-positive disease: Austrian breast and colorectal cancer study group trial 6. Journal of Clinical Oncology 21 984-990.

Shapiro CL \& Recht A 2001 Side effects of adjuvant treatment of breast cancer. New England Journal of Medicine 344 1997-2008.

Shapiro CL, Manola J \& Leboff M 2001 Ovarian failure after adjuvant chemotherapy is associated with rapid bone loss in women with early-stage breast cancer. Journal of Clinical Oncology 19 3306-3311.

Shaywitz SE, Shaywitz BA, Pugh KR, Fullbright RK, Kudlaski P, Mencl WE, Constable RT, Naftolin F, Palter SF, Marchione KE, Katz L, Shankweiler DP, Fletcher JM, Lacadie C, Keltz M \& Gore JC 1999 Effect of estrogen on brain activation patterns in postmenopausal women during working memory tasks. Journal of the American Medical Association 281 1197-1202.

Sicat BL \& Brokaw DK 2004 Nonhormonal alternatives for the treatment of hot flashes. Pharmacotherapy 1 79-93.

Smith I E \& Dowsett M 2003 Aromatase inhibitors in breast cancer. New England Journal of Medicine 348 2431-2442.

Smith RE \& Good BC 2003 Chemoprevention of breast cancer and the trials of the National Surgical Adjuvant Breast and Bowel Project and others. Endocrine-Related Cancer 10 347-357.

Stearns V, Johnson MD, Rae JM, Morocho A, Novielli A, Bhargava P, Hayes DF, Desta Z \& Flockhart DA 2003 Active tamoxifen metabolite plasma concentrations after coadministration of tamoxifen and the selective serotonin 
reuptake inhibitor paroxetine. Journal of the National Cancer Institute 95 1758-1764.

Tang MX, Jacobs D, Stern Y, Mander K, Schofield P, Gurland B, Andrews H \& Mayeux R 1996 Effect of oestrogen during menopause on risk and age at onset of Alzheimer's disease. Lancet 348 429-432.

Theriault RL, Lipton A, Hortobagyi GN, Leff R, Gluck S, Stewart JF, Costello S, Kennedy I, Simeone J, Seaman JJ, Knight RD, Mellars K, Heffernan M \& Reitsma DJ 1999 Pamidronate reduces skeletal morbidity in women with advanced breast cancer and lytic bone lesions: a randomized, placebo-controlled trial. Protocol 18 Aredia Breast Cancer Study Group. Journal of Clinical Oncology 17 846-854.

Twiss JJ, Waltman N, Ott CD, Gross GJ, Lindsey AM \& Moore TE 2001 Bone mineral density in postmenopausal breast cancer survivors. Journal of the American Academy of Nurse Practitioners 13 276-284.

Vassilopoulou-Sellin R, Asmar L, Hortobagyi GN, Klein MJ, McNeese M, Singletary SE \& Theriault RL 1999 Estrogen replacement therapy after localized breast cancer: clinical outcome of 319 women followed prospectively. Journal of Clinical Oncology 17 1482-1487.

Vogel VG, Costantino JP, Wickerham DL, Cronin WM \& Wolmark N 2002 The study of tamoxifen and raloxifene: preliminary enrollment data from a randomized breast cancer risk reduction trial. Clinical Breast Cancer 3 153-159.

Wassertheil-Smoller S, Hendrix SL, Limacher M, Heiss G, Kooperberg C, Baird A, Kotchen T, Curb JD, Black H, Rossouw JE, Aragaki A, Safford M, Stein E, Laowattana S \& Mysiw WJ 2003 Effect of estrogen plus progestin on stroke in postmenopausal women: the Women's Health Initiative: a randomized trial. Journal of the American Medical Association 289 2673-2684.

Wilcken N, Hornbuckle J \& Ghersi D 2003 Chemotherapy alone versus endocrine therapy alone for metastatic breast cancer (Cochrane review). Cochrane Database of Systematic Reviews CD002747.

Winer EP, Hudis C, Burstein HJ, Chlebowski RT, Ingle JN, Edge SB, Mamounas EP, Gralow J, Goldstein LJ, Pritchard KI, Braun S, Cobleigh MA, Langer AS, Perotti J, Parles TJ, Whelan TJ \& Browman GF 2002 American Society of Clinical Oncology technology assessment on the use of aromatase inhibitors as adjuvant therapy for women with hormone receptor-positive breast cancer: status report 2002. Journal of Clinical Oncology 20 3317-3327.

Wluka AE, Cicuttini FM \& Spector TD 2000 Menopause, oestrogens and arthritis. Maturitas 35 183-199. 